Insight

\title{
The Managed Recession of Lake Okeechobee, Florida: Integrating Science and Natural Resource Management
}

\author{
$\underline{\text { Alan Steinman }}^{1}, \underline{\text { Karl Havens }}^{2}$, and Lewis Hornung ${ }^{2}$
}

\begin{abstract}
Resource management decisions often are based on a combination of scientific and political factors. The interaction of science and politics is not always apparent, which makes the decision-making process appear arbitrary at times. In this paper, we present a case study involving Lake Okeechobee, a key environmental resource in South Florida, USA, to illustrate the role that science played in a high-profile, highly contentious natural resource management decision. At issue was whether or not to lower the water level of Lake Okeechobee. Although scientists believed that a managed recession (drawdown) of water level would benefit the lake ecosystem, risks were present because of possible future water shortages and potential environmental impacts to downstream ecosystems receiving large volumes of nutrient-rich fresh water. Stakeholders were polarized: the agriculture and utility industries favored higher water levels in the lake; recreation users and businesses in the estuaries wanted no or minimal discharge from the lake, regardless of water level; and recreation users and businesses around the lake wanted lower water levels to improve the fishery. Jurisdictional authority in the region allowed the Governing Board of the South Florida Water Management District to take emergency action, if so warranted. Based on information presented by staff scientists, an aggressive plan to release water was approved in April 2000 and releases began immediately. From a hydrological perspective, the managed recession was a success. Lake levels were lowered within the targeted time frame. In addition, water quality conditions improved throughout the lake following the releases, and submerged plants displayed a dramatic recovery. The short-term nature of the releases had no lasting negative impacts on downstream ecosystems. Severe drought conditions developed in the region during and following the recession, however. Severe water use restrictions were implemented for several months. There also were impacts to the local economy around the lake, which depends heavily on recreational fishing; use of boat launch areas was curtailed because of the low water levels in the lake. This case study provides an example of how science was used to justify a controversial decision. Although the environmental basis for the decision was validated, unexpected or unpredictable climatic results led to socioeconomic challenges that offset the environmental successes.
\end{abstract}

\section{INTRODUCTION}

Natural services provided by ecosystems, such as nutrient filtration, carbon sequestration, biodiversity, and food production, are being threatened by human influences at a global scale (Matson et al. 1997, Vitousek et al. 1997, Wackernagel et al. 2002). Indeed, many ecosystems are already imperiled or damaged because of human activities (e.g., Carpenter et al. 1998). Ecosystem restoration is often attempted to revitalize these services in damaged systems (NRC 1992), but the process by which management decisions regarding restoration are made is rarely transparent. Although both resource managers and scientists acknowledge explicitly that restoration efforts must be based on sound science (e.g., NRC
1992, Dahm et al. 1995), it is not always apparent how science is used by managers and whether the science becomes marginalized during the decision-making process.

Science provides a necessary framework for helping to predict or understand the outcomes of a restoration project. However, these projects often have unexpected outcomes. This may be because: (1) natural systems are complex and behave in unpredictable ways; (2) political realities result in modified project design elements; or 3 ) the science upon which the design elements were based was either immature or incorrect. Because these restoration projects can be exceedingly expensive, it is imperative that society has confidence in the ability of scientists,

\footnotetext{
${ }^{1}$ Annis Water Resources Institute, Grand Valley State University; ${ }^{2}$ South Florida Water Management District
} 
engineers, planners, and elected officials to design and implement successful projects. In those cases in which unexpected outcomes emerge, there is a need to identify why the outcome did not match the expectation; conversely, for those projects that are successful, it is essential to understand what was done correctly so that the appropriate processes can be incorporated into the design of future projects.

This paper presents a case study involving Lake Okeechobee, one of the largest lakes in the United States. It describes how science and management interacted to address what the public and media declared to be an environmental emergency. This paper discusses the management decision to lower water levels in Lake Okeechobee, and includes the scientific basis behind the decision, the process by which the decision was made, and the implications and outcomes associated with the decision. Although the degree to which the findings in this study can be applied to other projects will vary, it is our intention to use this case study to shed light on the often opaque process regarding the role of science in resource management decisions.

Certain ecological and societal values associated with Lake Okeechobee, such as fishing and wildlife, recreation, and fresh water for the Everglades, have been threatened by a combination of human influences and natural events, including nutrient enrichment, invasive species, and unnatural hydroperiods (Aumen 1995, Havens et al. 1996, Steinman et al. 1999, 2001). Unusually high water levels through much of the 1990s were believed by a variety of scientists and citizens to have resulted in ecological damage to the lake's resources (Havens et al. 2001, Steinman et al. 2001). Because lake levels are controlled, in part, by a regulation schedule, it is possible to lower the lake by opening flood control gates to release water to the connecting estuaries. However, different stakeholders in the region place different values on the water in the lake, which result in conflicting opinions about what equates to a desirable water level.

Operational decisions regarding Lake Okeechobee are made by the U.S. Army Corps of Engineers (USACE) and the South Florida Water Management District (SFWMD), who operate the lake pursuant to the Water Control Plan for Lake Okeechobee and the Everglades Agricultural Area, which is a federal regulation. The Water Control Plan includes regulatory (flood control) discharges, water supply deliveries to permitted users, and deliveries for water quality protection in downstream ecosystems. When lake levels are high, regulatory releases of water occur under the authority of a USACE regulation schedule, which is one facet of the overarching Water Control Plan. Releases for water supply (at any lake level) occur under the authority of the SFWMD, the agency responsible for allocating water to permitted users in the Water Control Plan. As part of this overall process, lake operations are regularly discussed at public meetings where stakeholders and representatives from other federal, state, and tribal agencies have an opportunity for input. Examples include monthly meetings of the SFWMD Governing Board and quarterly meetings related to the USACE regulation schedule. Stakeholders also provide input by informal means, including the lobbying of elected officials and discussions with members of the Governing Board or staff members at the SFWMD.

\section{LAKE OKEECHOBEE: A BRIEF HISTORY}

Lake Okeechobee, located at approximately $27^{\circ} \mathrm{N}$ latitude and $81^{\circ} \mathrm{W}$ longitude (Fig. 1), has a surface area of approximately $730 \mathrm{~km}^{2}$ and a mean depth of $2.7 \mathrm{~m}$. It is naturally eutrophic, but has undergone cultural eutrophication and its average annual total phosphorus concentration in the water column has increased from about $40 \mu \mathrm{g} / \mathrm{L}$ in the early 1970 s to about $110 \mu \mathrm{g} / \mathrm{L}$ in 2001 (Havens and Schelske 2001).

Although all lakes provide many services (Postel and Carpenter 1997), Lake Okeechobee is probably at the extreme end of the continuum in terms of the number of services that it provides, the diversity of its users, and the tremendous economic interest in its health and fate. Lake Okeechobee currently faces three major environmental problems: (1) excessive phosphorus loads; (2) rapid spread of nuisance and exotic plants; and (3) unnaturally high and low water levels because the lake is managed for multiple purposes including water supply and flood control. Indeed, one of the most challenging management issues continues to be striking a balance between the growing demands for water supply and flood control, and the need to protect the health of the lake and the downstream ecosystems.

Fig. 1. Current flow patterns in the KissimmeeOkeechobee-Everglades ecosystem, Florida, USA. The headwaters for the ecosystem are located in the Upper Chain of Kissimmee Lakes, at the top of the figure. The water from these lakes enters into Kissimmee River, which discharges into Lake Okeechobee, in the middle of the 
figure. Depending on lake stage, water flows from the Lake south through a series of canals into either Florida Bay or the Atlantic Ocean, east through the St. Lucie Canal into the Atlantic Ocean, and/or west through the Caloosahatchee River into the Gulf of Mexico. Source: Comprehensive Everglades Restoration Plan (USACE 1999).

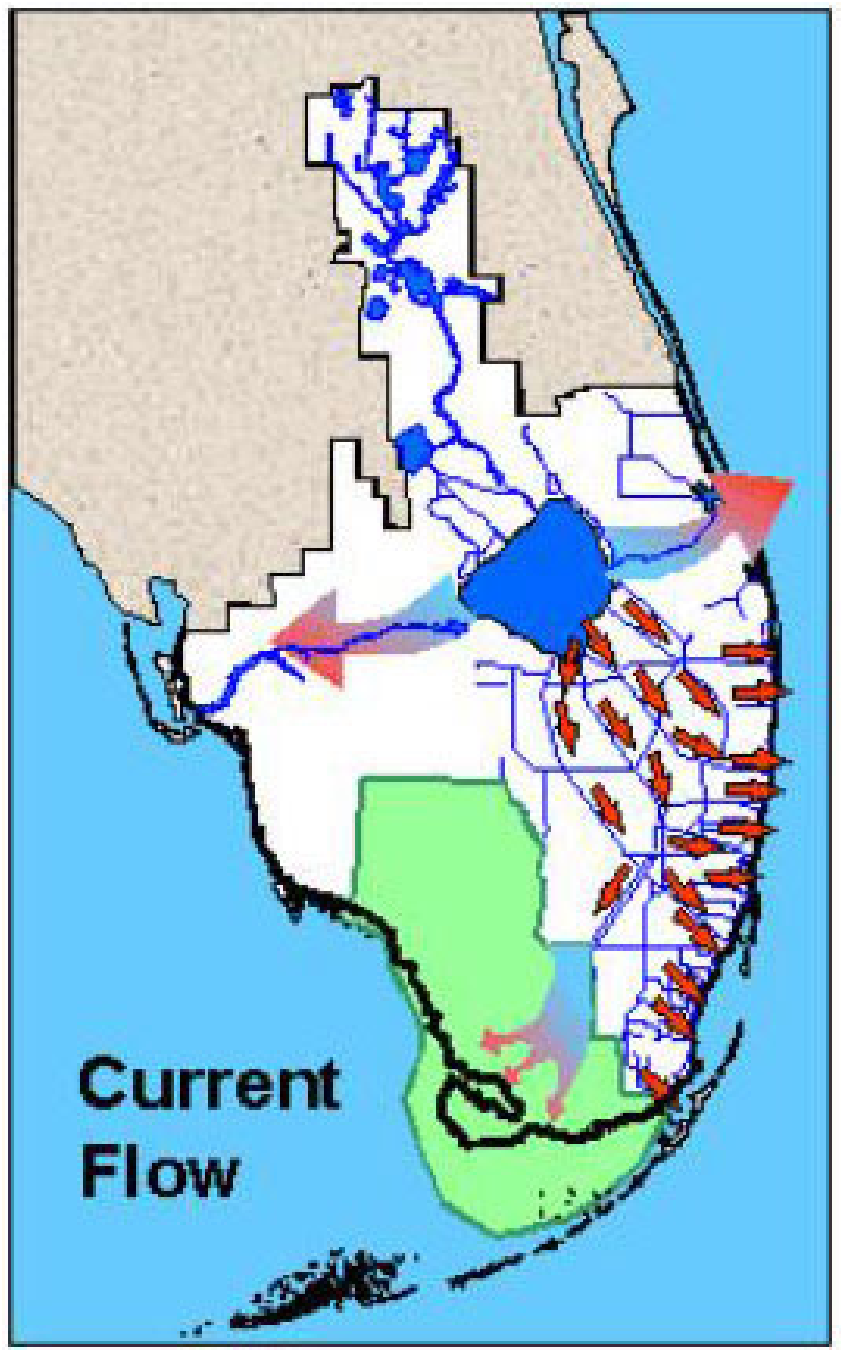

Lake Okeechobee is an extremely managed system; humans play a large role in the control of water levels. The lake is encircled by a $10.4 \mathrm{~m}$ high earthen levee, built in response to catastrophic hurricanes that resulted in thousands of human deaths in the late 1920s. Today, all inflows and outflows except one are regulated by water-control structures (Steinman et al. 2001). Lake stage is controlled, in part, by a prescribed regulation schedule, administered jointly by the SFWMD and the USACE. This schedule determines the timing and quantity of water that is to be released from the lake when the stage exceeds a defined level, which varies with season, antecedent hydrologic conditions, and long-range climatic forecasts. The schedule has been modified over time to reflect changing philosophies. The current schedule was adopted in 2000 and was designed to be more responsive to environmental needs of the lake and downstream ecosystems. More details on this regulation schedule can be found at http://www.sfwmd.gov/org/pld/hsm/reg app/lok reg/i ndex.html.

Following an extreme El Niño event in 1998, when lake levels rose to the point at which the integrity of the levee was in jeopardy, maximum regulatory releases were made to the connecting estuaries. Shortly thereafter, 33 species of fish in the St. Lucie Estuary were observed to have lesions and ulcers (SFWMD 1999). An aquatic fungus is believed to be the causative agent, and although no direct link was made to the Lake Okeechobee releases, the proximity of the events pointed to lake discharge as a possible cause. These events resulted in more pressure from the public to keep lake levels lower to avoid the need for these types of regulatory discharges. Starting in 1999, weekly meetings were held via telephone between engineers, scientists, and managers at the USACE and SFWMD to discuss water levels and operational decisions. Stakeholder input was obtained at quarterly public meetings and at regular meetings of the SFWMD Governing Board.

Complicating the regulation schedule for Lake Okeechobee is its multifaceted role in the region. The lake is designated as a Class I water (potable water supply), and serves multiple purposes, including: water supply for agriculture, municipalities, and industry; recharge for wellfields; fresh water for the Everglades; habitat for fish and wildlife, including numerous threatened and endangered species; flood control; navigation; and recreational activities.

Water resource managers faced a dilemma, considering these competing demands on the lake and the fact that the demands, in many cases, were mutually exclusive. For example, the agricultural community and utilities preferred to keep the lake level high to ensure adequate water supply for their crops and developed land uses, respectively. Estuarine recreational users did not care about water level, per se, as long as their estuaries did not receive any discharges from the lake. The recreational users of the lake and the associated tourism industry wanted a hydroperiod that reflected natural (i.e., pre-levee) conditions, with higher levels in the rainy season and a dry season recession, to ensure a healthy fishery in Lake Okeechobee. Finally, lakeshore municipalities 
wanted to make sure that there was sufficient water for their intake pipes to obtain water (Table 1).

Decisions regarding water policy in South Florida are set by the nine-member Governing Board of the SFWMD, which consists of people appointed by the Governor of Florida from throughout the 16-county South Florida region. Staff scientists and engineers at the SFWMD present their research findings and best professional judgments to the Governing Board at monthly workshops and meetings, and this information is taken under advisement. Staff presented regular updates on the hydrologic and ecological status of Lake Okeechobee and the estuaries to the Governing Board from 1998 through 2000. Fifteen presentations alone were presented to the Governing Board by the senior author (A. D. Steinman) of this paper during this time period.

In addition to pressures from citizenry and the media, new legislation was being drafted by the Florida legislature on a Lake Okeechobee Protection Act (HB991). Although this legislation was driven more by concerns over pollution than water levels, it contributed to the heightened attention being focused on the lake. The sponsor of the legislation, Representative Ken Pruitt, was chair of the House Appropriations Committee in the Florida legislature. His district encompassed the St. Lucie Estuary, which experienced the problems associated with large freshwater discharges less than two years earlier. Hence, he was very interested in the ecological condition of the lake and how it was managed. Weekly phone calls between Representative Pruitt or his staffers and the senior author of this paper (A. D. Steinman) were not uncommon when the Florida Legislature was in session, and A. D. Steinman was obligated to report the substantive content of these phone conversations to the Director of the SFWMD's Office of Counsel.

\section{EVENTS LEADING UP TO THE MANAGED RECESSION DECISION}

The issue of high water level waxed and waned through much of the 1990s. Lake levels had remained higher than average from 1990 through May 2000 (Fig. 2), rarely falling below a lake stage of $3.97 \mathrm{~m} \mathrm{(13}$ feet). High lake stage was due primarily to heavy rainfall in the watershed and over the lake, but this probably was exacerbated by a prior regulation schedule that tended to hold water in the lake even when levels were above $4.5 \mathrm{~m}$ (14.76 feet; SFWMD
1997). In the summer of 2000, scientists from the Florida Fish and Wildlife Conservation Commission presented unpublished fish survey data indicating that juvenile bass (Micropterus salmoides) were being found at all-time low levels in Lake Okeechobee, and attributed the decline to the loss of submerged plant habitat. The recreational users and commercial interests associated with Lake Okeechobee raised the issue of high water levels at monthly meetings of the SFWMD Governing Board through the fall and winter of 1999-2000, as well as to elected officials and representatives from the print media. Indeed, the Palm Beach Post printed a three-part series in the fall of 2000, which culminated in a lead editorial entitled "Keeping Lake Okeechobee out of Nature's Morgue."

Fig. 2. Mean monthly lake stage of Lake Okeechobee, Florida, USA from 1973 through 2000. Note the relatively few occurrences when lake stage dropped below 13 feet (about $3.96 \mathrm{~m}$ ) since 1990.

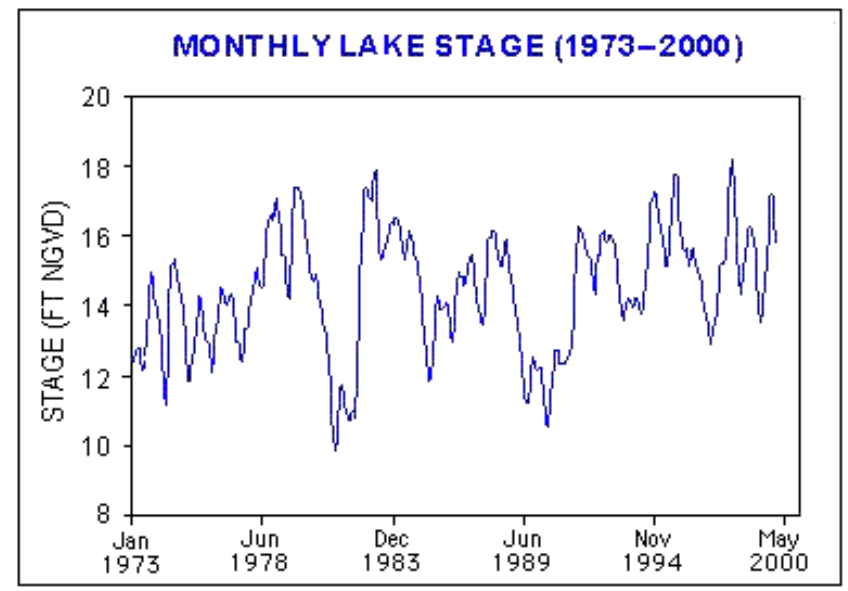

The rhetoric was rising through 1999 and 2000, and some stakeholders began to proclaim that Lake Okeechobee was dying. Data collected by scientists at the SFWMD documented that high lake stages had the following impacts on the ecology of Lake Okeechobee:

1) Less light reached the bottom of the lake, resulting in loss of submerged vegetation (Chara, Potamogeton, Vallisneria; Steinman et al. 1997, 2002, Havens et al. 2001).

2) Increased turbidity resulted in light limitation of bulrush (Scirpus sp.), which may have weakened the plants, making them more susceptible to uprooting by 
wind-driven waves (C. Hanlon and M. Brady, unpublished data).

3) Increased phosphorus concentrations in the nearshore regions, as phosphorus-rich sediments were transported from the central mud zone toward the littoral zone (Havens and James 1999).

4) Internal waves within the lake's water column spread the loose sediments from the center of the lake to shoreline areas, resulting in more turbid, nutrientrich water reaching this sensitive area (Havens and James 1999), where much of the lake's submerged plants and fish/wildlife habitat occur (Aumen and Wetzel 1995).

5) There may have been a reduced rate of spread of invasive species in the lake's marsh zone, such as Panicum repens (torpedograss) and Melaleuca quinquenervia, based on extrapolation of results from small-scale, experimental manipulations (unpublished data). Both of these species can tolerate flooded conditions, but appear to increase in coverage following dry conditions (David 1999, Hanlon and Langeland 2000).

Nevertheless, releases of water to the estuaries (the main outlets from the lake) were kept relatively low during this period of time, reflecting the prevailing desires to keep water stored in the lake and minimize salinity imbalances in the estuaries if at all possible.

Seven of the nine years between 1991 and 1999 exhibited above-average rainfall over Lake Okeechobee and its tributary drainage basin. Observations from monthly monitoring cruises suggested that the lake's submerged aquatic vegetation (SAV) community had severely declined. As a consequence, a 42-station sampling program was initiated in April 1999. Samples were taken along 14 fixed transects (three sites per transect) that extended from the lakeshore outward around the south, west, and north lake perimeter (Fig. 3), as described in Havens et al. (2001).

The loss of SAV threatened the survival of a multimillion dollar sport fishery, which previously had been documented to rely on this habitat (Furse and Fox 1994). Scientists, resource managers, and concerned members of the public reached a consensus that unless a sustained period of more moderate (i.e., at or below $4 \mathrm{~m}$ ) lake level was to occur, many of the ecological and societal values of the resource might be lost.
Based on prior studies in Lake Okeechobee (Steinman et al. 1997, Havens and James 1999), consultation with outside experts, and the best professional judgment of scientists at the SFWMD, Florida Fish and Wildlife Conservation Commission, and the USACE's Waterways Experiment Station, it was concluded that if the lake level could be lowered to 13 feet (approximately $4 \mathrm{~m}$ ) for at least 8 weeks, conditions would be favorable for reestablishing a healthy SAV community in Lake Okeechobee. An 8-week period was considered the minimum time necessary to allow plants to germinate and grow to a size that could tolerate deeper flooding. However, keeping the lake at about $4 \mathrm{~m}$ from 1 June through 1 August was viewed as potentially difficult because it coincided with the wet season in South Florida, when increased inflows to Lake Okeechobee normally cause water levels to increase rapidly.

Fig. 3. Location and relative abundance of submerged aquatic vegetation (SAV) sampled during July 1999 in Lake Okeechobee. All stations sampled in 1999 had abundant vegetation when sampled in 1991 (Zimba et al. 1995).

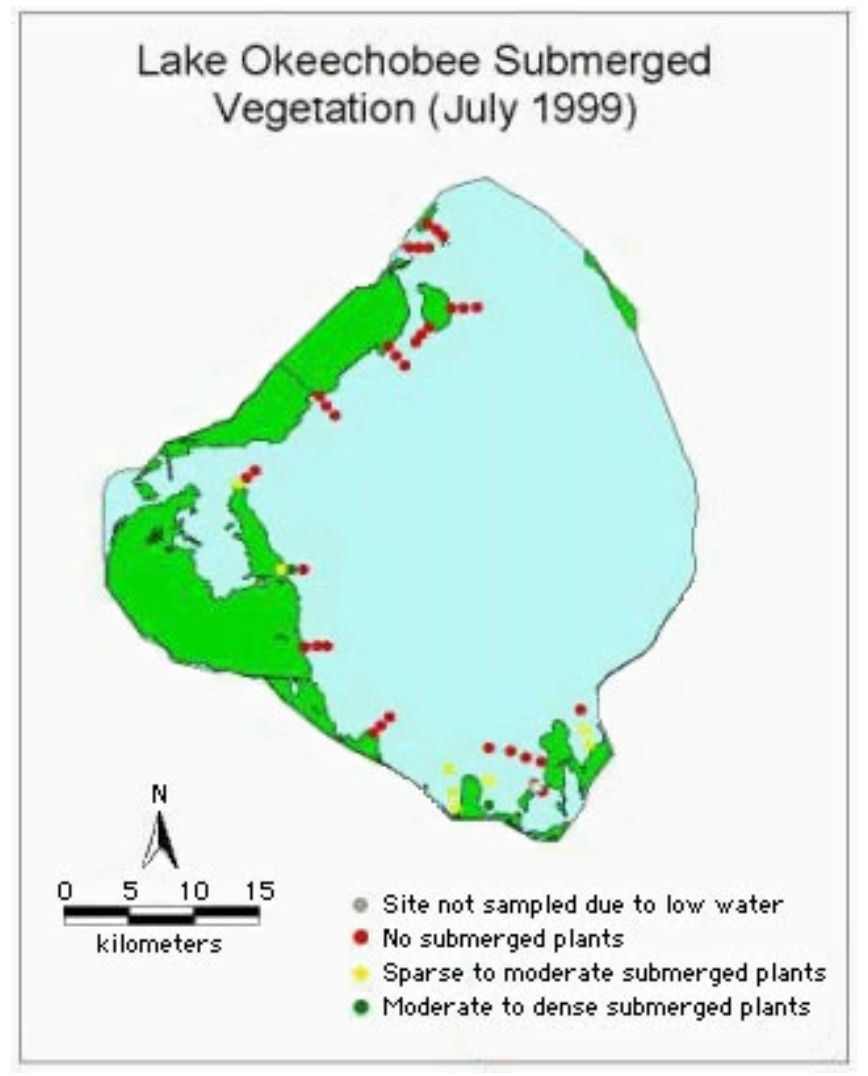

The lowering of lake level was a controversial decision that included scientific, economic, social, and 
political uncertainties. In addition to the ecology of the lake, any decision regarding the lowering of lake levels needed to consider the following potential impacts:

1) altered salinity regimes due to lake discharges to the downstream estuaries;

2) increased phosphorus loading from lake discharges to the Everglades; and

3) risk of reduced water supply for agricultural, utilities, and the natural environment if conditions following the recession became drier than expected.

By the spring of 2000, the combination of documented environmental problems, stakeholder and media concerns, and political pressures made some level of action inevitable. Given the potential socioeconomic risks associated with a managed recession of Lake Okeechobee, a series of public meetings throughout South Florida was held in spring 2000 in the cities of: (1) Fort Myers, with stakeholders in southwest Florida concerned about the Caloosahatchee Estuary, (2) Okeechobee, with stakeholders concerned about Lake Okeechobee, and (3) West Palm Beach, with stakeholders throughout the region and state. This final meeting, held on 19 April 2000, included presentations from SFWMD scientific staff on hydrologic modeling results, NOAA (National Oceanic and Atmospheric Administration) climate forecasts, and performance measures that could be used to evaluate ecosystem responses to a managed recession. It was followed by break-out groups who dealt with water supply, Everglades, estuaries, and Lake Okeechobee, and then reconvened for a general discussion of the available options. In addition, phone conversations and meetings were held with representatives of state, federal, and tribal agencies, in order to explain the nature of the problem and solicit ideas. Based on the list of available options, and with input from upper management at the South Florida Water Management District, staff sorted the public input recommendations into the following categories: not feasible (due either to logistical constraints of the water control structures or to legal considerations); feasible with minimal logistical and political implications (i.e., could be implemented under authority of the SFWMD); and feasible, but with considerable logistical and political implications (i.e., possibly could be implemented but not without further discussions with other agencies and political entities). Using these categories as guidelines, and again with input from upper management at the
SFWMD and members of the Governing Board, staff from the SFWMD developed three alternative plans to be presented to the Governing Board for their consideration:

Base Plan: take no action; let nature take its course.

Public Input Plan: carry out low-volume discharges of water from the lake, at a level that would not impact the salinity of estuaries or present a significant risk to future water supply (based on model runs).

Shared Adversity Plan: carry out large-volume discharges from the lake in order to lower the stage to about $4 \mathrm{~m}$ in a short period of time, and hold the stage low for at least 8 weeks.

\section{THE MANAGED RECESSION DECISION}

On 25 April 2000, these three plans, along with an analysis outlining their relative risks and benefits, were presented by scientific staff at an emergency meeting of the SFWMD's Governing Board. Presentations by hydrologists, meteorologists, and ecologists to the Governing Board identified several important water resource elements that appeared to provide the SFWMD with a unique opportunity to carry out a successfully managed recession in Lake Okeechobee:

Low rainfall in the preceding two months reduced the probability of high runoff in the subsequent weeks, if rainfall were to occur. This increased the chance that a prolonged period of low water levels $(<4 \mathrm{~m})$ could be maintained.

There was a higher probability of lower than average rainfall for the remainder of the 2000 dry season because La Niña conditions existed. Dry conditions would reduce inflows and make it possible to maintain lower lake stages for the 8-wk minimum duration, with less impact to the estuaries and Everglades.

Over the historic period of record, no La Niña event had ever persisted for three consecutive years. Because 2000 was the second consecutive La Niña year, it was assumed that the probability of a third dry season with significantly below average rainfall in early 2001 was relatively low. Thus, the risk to future water supply was projected to be relatively low.

In addition, the scientific staff reported to the Governing Board that the Climate Prediction Center 
(CPC) of the National Oceanic and Atmospheric Administration was consistently predicting aboveaverage rainfall in the late wet season of 2000. If these predictions proved correct, this would provide the much-needed water supply volume at an optimal time for human use (i.e., during the influx of winter residents), as well as a time that would have minimal impact on the new vegetation in the littoral zone.

Also presented to the Governing Board by scientific staff were results from the South Florida Water Management Model (SFWMD 1997), a regional-scale hydrologic model that simulates the hydrology of the highly managed water system in South Florida. This model was used to evaluate potential impacts associated with alternative operational strategies. The model was initialized with the existing hydrologic conditions and then run in Position Analysis (Hirsch 1978, Tasker and Dunne 1997, Cadavid et al. 1999) mode. The position analysis approach takes the last 31 years of rainfall data (1965-1995) in the region, along with the present lake stage, and produces a series of graphs showing probabilities of certain lake stages over the subsequent three months. The output graphs are based on frequency of occurrence of different rainfall patterns in the past years.

Position Analysis resulted in a set of probability functions for lake stage (Table 2). If no actions were taken (Base Plan), the lake level was projected to decline to $4.36 \mathrm{~m}$ on 1 June 2000 (from $4.53 \mathrm{~m}$ on 25 April) due to evapotranspiration and water supply deliveries (Table 2). Based on the $30-y r$ period of record, there had never been an occurrence in which the lake dropped on its own in that time frame to 3.97 $\mathrm{m}$, or even to $4.12 \mathrm{~m}$ (Table 2). Results were similar for the Public Input Plan, although the projected lake level on 1 June was somewhat lower, and there was a small probability of reaching $4.12 \mathrm{~m}$ (Table 2). The probability of meeting the hydrologic goal was substantially greater with the Shared Adversity Plan. The reason that the probability of meeting the $3.97 \mathrm{~m}$ goal was only $80 \%$ (instead of $100 \%$ ) for this plan was that if the period between 25 April and 1 June was exceptionally wet, there would not be enough conveyance capacity to move water out of the lake fast enough to offset the increased flows from the watershed.

Risks also were addressed for each Plan relative to downstream impacts on the estuaries and Everglades, and to water supply. Based on projected discharges associated with each Plan, models were developed to determine the change in salinity, and duration of change, to the Caloosahatchee and St. Lucie estuaries. These changes were then related to controlled experiments that had been conducted on the salinity tolerances of the dominant SAV in the Caloosahatchee estuary and to prior observational studies on the salinity tolerances of oysters in both estuaries (Doering et al. 1999, Kraemer et al. 1999). For the Everglades, assessments were made for the potential impact of each Plan on tree islands, wading birds, and phosphorus loads from canals draining Lake Okeechobee into the adjacent marshes. During the recession operation, when maximal water discharges were occurring into canals passing through the Everglades Water Conservation Areas, a full day of spatially intensive flow measurements were conducted. The objective was to determine whether water was moving from the canal into the adjacent Everglades wetlands, where it might negatively impact the attributes listed previously.

Finally, water supply risks were evaluated for each Plan. Lake Okeechobee is the primary source of water for users located around its perimeter. It also provides a back-up water supply for the urbanized area of Florida's lower east coast and water for recharging the Biscayne aquifer so that saltwater intrusion does not occur. Probabilities of imposing water supply restrictions (Table 3) were based on output from the Position Analysis modeling, by evaluating the likelihood that future lake stages would result in situations in which water users experience restrictions under a SFWMD program called "supply side management" (Hall 1992).

Immediately following the presentation of the specifics and risks of the three plans, the Governing Board of the SFWMD adopted Resolution No. 00-31, also known as the Shared Adversity Plan (SFWMD 2000). Although this plan had the greatest potential to meet the desired ecological outcome for Lake Okeechobee, it also had the highest risk for impacting the estuaries, the Everglades, and water users surrounding and depending on the lake. As a consequence, the potential risks and adversity were shared among the stakeholders, resulting in its name.

The Shared Adversity Plan was implemented immediately after adoption. Discharges to the east, west, and south continued for 27 days, at which point releases from the lake were terminated on 21 May 2000. On that date, the lake level had fallen from an average elevation of $4.54 \mathrm{~m}$ to $3.97 \mathrm{~m}$. 
Fig. 4. Typical discharge ranges that occurred during the peak discharge period of the managed recession (25 April 2000-21 May 2000).

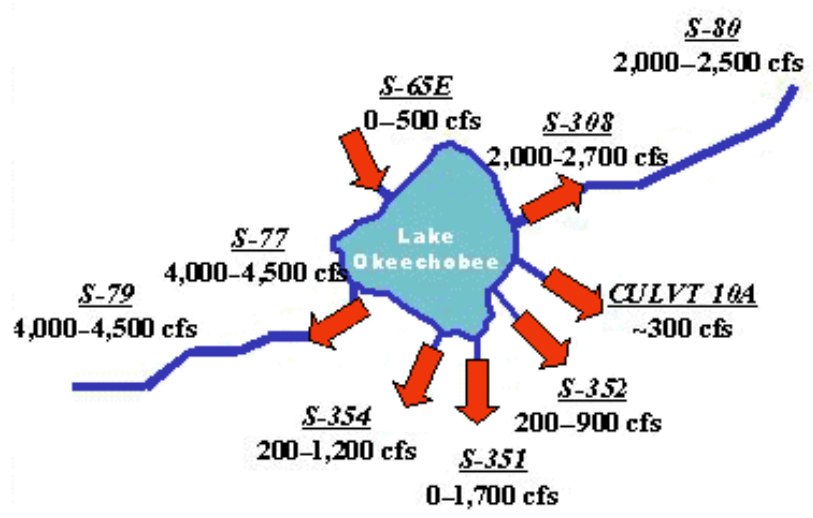

The operational guidelines for the Shared Adversity Plan called for releases from the lake at every major outlet structure (Fig. 4). Maximum practicable releases were sent east to the St. Lucie estuary and west to the Caloosahatchee estuary. Lake Okeechobee recession releases also were sent south into the Water Conservation Areas (WCAs) under a variety of conditions. Every effort was made to maintain as much water in the system as possible, rather than losing potential water supply to tide, although hydrologic conditions greatly limited this effort. In addition, the Plan called for a scientifically based monitoring plan to be implemented immediately to evaluate effects of the managed recession on Lake Okeechobee, the Everglades, and the downstream estuaries.

\section{OUTCOMES OF THE MANAGED RECESSION PLAN}

The managed recession operation had a number of ecological, social, and political effects, although in some cases it is impossible to tease apart outcomes associated with the managed recession per se vs. those associated with the subsequent drought:

Hydrology. The hydrologic goal of lowering water levels in Lake Okeechobee to $3.97 \mathrm{~m}$ was met on 21 May 2000, 10 days earlier than anticipated, due to the extremely dry conditions during the recession (Fig. 5). The additional goal of maintaining water level at or below $3.97 \mathrm{~m}$ for 8 weeks also was met, as summer 2000 was one of the driest on record in South Florida. The loss of water directly attributable to the managed recession was estimated to be approximately $0.30 \mathrm{~m}$, with evapotranspiration accounting for the additional lost water. Lake levels continued to drop through the summer (Fig. 5), as areas north of the Lake experienced a severe hydrologic drought and provided no inflow.

Fig. 5. Hydrograph of Lake Okeechobee from January 2000 through 15 December 2001. The managed recession began in April 2000. A severe drought from May 2000 through July 2001 resulted in the lowest lake level in recorded history. (Depth conversion: feet x $0.304801=$ meters.)

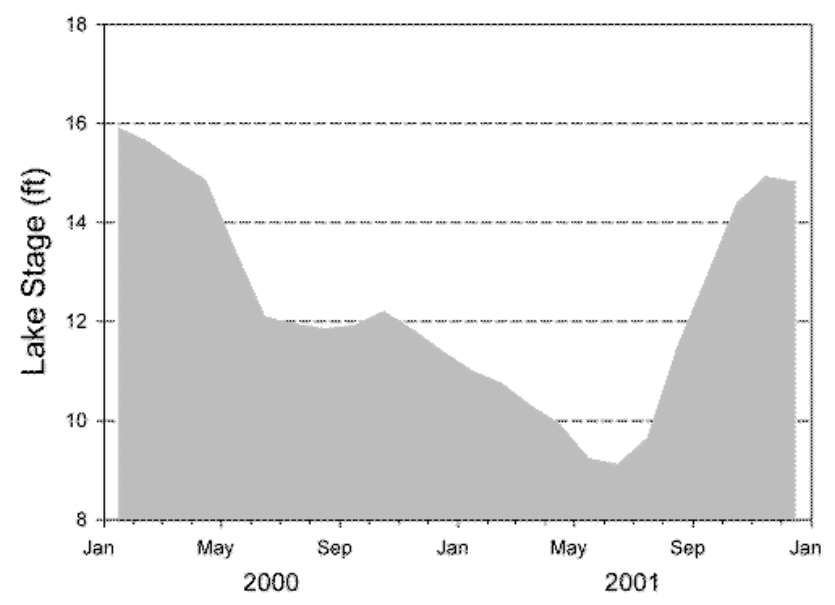

Lake Okeechobee. Over the course of the 2000 summer, transparency in the water column increased from 20-30 $\mathrm{cm}$ to near $1 \mathrm{~m}$ (near bottom) and phosphorus concentrations declined from about 60-70 $\mu \mathrm{g} / \mathrm{L}$ to near $20-30 \mu \mathrm{g} / \mathrm{L}$, in regions where SAV recovered (Havens et al. 2001). The number of sites with SAV increased from two (of 42) in April 2000 (just prior to the managed recession) to 23 sites in August 2000 (Fig. 6).

A lake survey was conducted in October 2000 for presence-absence of SAV (Havens et al. 2002). Based on this survey, it was estimated that SAV covered > 17,000 ha in Lake Okeechobee (Fig. 7). This is similar to the spatial extent documented in a survey of the SAV in 1989-1991, coincident with another severe drought and low lake stage (Zimba et al. 1995). Although a comparable survey was not conducted prior to the managed recession in 2000, based on our transect sampling, we estimated that SAV cover in October 1999 was no more than 1200 ha. Additional 
environmental responses to the recession can be found in Havens et al. (2001) and Steinman et al. (2002).

Monitoring of invasive species suggested that torpedograss continued to expand its cover in the littoral zone of Lake Okeechobee. Sampling of plant densities in reference plots that had been monitored since 1999 indicated that during the drought period, the rate of expansion of torpedograss increased by two- to threefold. However, the drought also provided dry conditions that allowed the SFWMD and coordinating agencies to carry out controlled fires and treatments of torpedograss with herbicide. These treatments continued through 2001, and as of July 2002, treated areas were not displaying significant regrowth of torpedograss.

Fig. 6. Presence-absence of SAV (submerged aquativ vegetation) in Lake Okeechobee prior to (left panel) and 4 months following the managed recession of Lake Okeechobee.

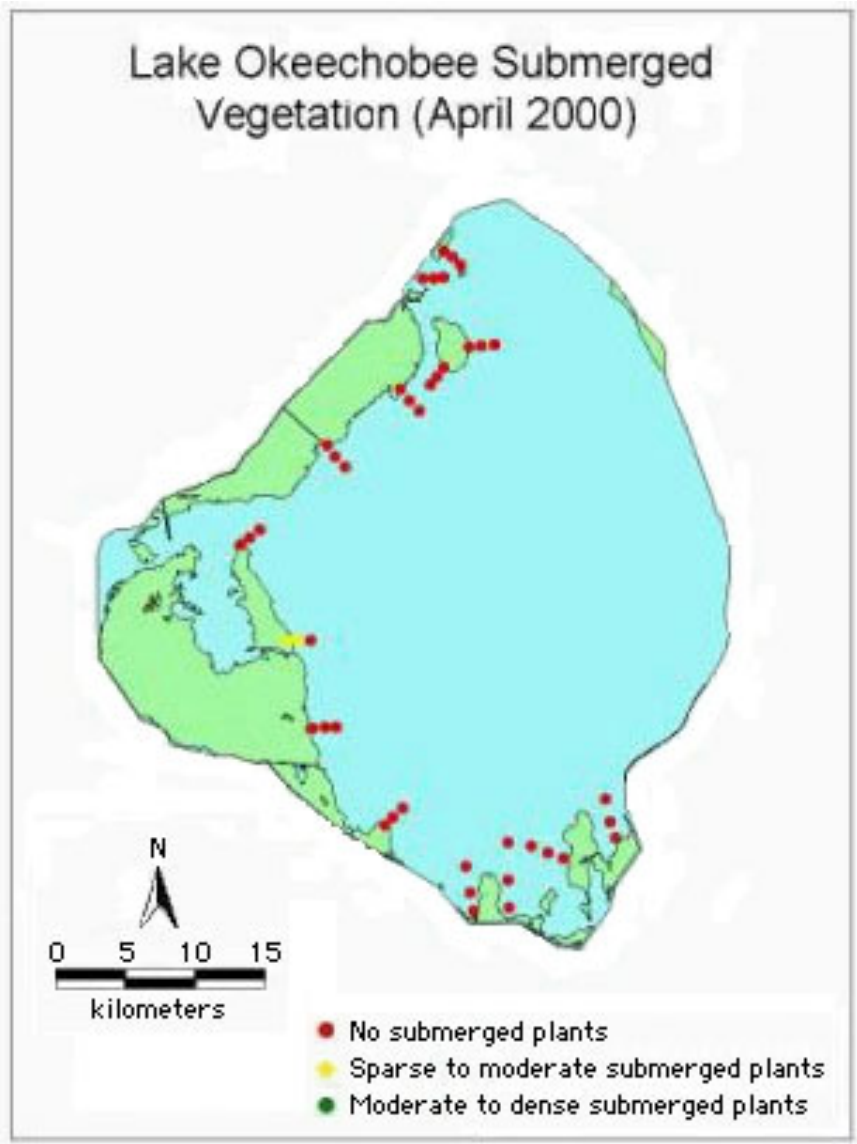

Estuaries. Monitoring conducted as part of the managed recession revealed results consistent with prior research at the SFWMD, which indicated that short-term releases of water can have immediate, negative impacts, but that these systems are resilient (Doering et al. 1999, Kraemer et al. 1999). Once discharges to the St. Lucie Estuary ceased, turbidity subsided within four days and salinity returned to ranges tolerable to oysters within one week. Impacts to seagrasses along the Atlantic coastline were localized and did not persist past June 2000. Recovery of

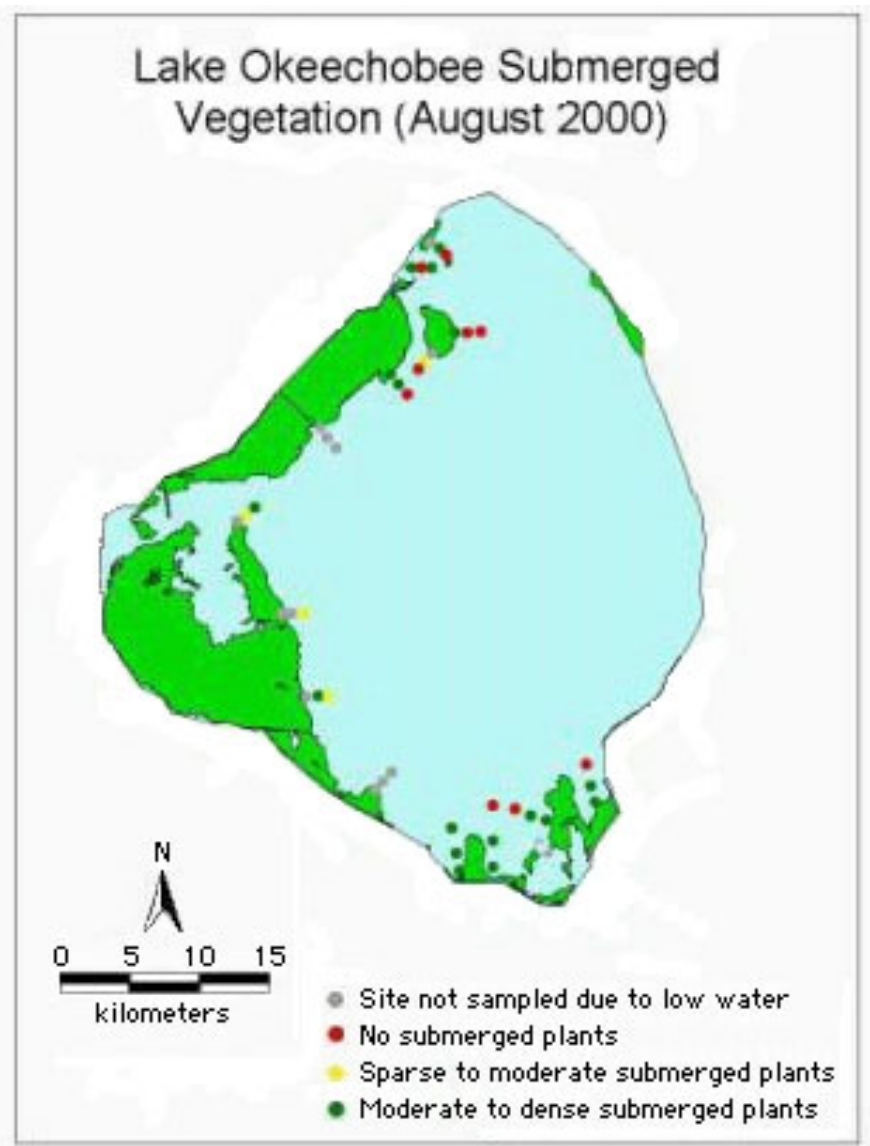

environmental conditions was slower in the Caloosahatchee Estuary because there was seagrass mortality in the lower estuary. A cyanobacterial bloom (Anabaena spp.) was documented in the upper estuary, presumably related to the recession operation. A working hypothesis is that the water from Lake Okeechobee "seeded" the estuary with cyanobacteria, which then proliferated to bloom levels in a subsequent period when flow was maintained at near $300 \mathrm{cfs}$ (about $8.5 \mathrm{~m}^{3} / \mathrm{s}$ ) for a number of weeks, keeping conditions oligohaline. This low flow rate 
maintained an isohaline front near the city of Fort Myers. The bloom ended when freshwater discharges were stopped and salinity levels began to increase.

Everglades. Impacts of the managed recession on the Everglades were minimal. There was no apparent impact on tree islands as a result of the Shared Adversity Plan. In addition, the year 2000 turned out to be one of the most successful nesting seasons in several decades for wading birds in the Everglades as a whole (SFWMD 2001). Because the managed recession took place late in the spring, much of the nesting season was already completed and not impacted by the releases. Flow sampling during the recession revealed that relatively little canal-to-marsh water exchange occurred, because many of the marsh water levels were below land surface. There were no apparent water quality impacts, as determined from phosphorus sampling in the marshes and canals during the course of the recession.

Water supply. Contrary to model predictions, the region experienced a serious drought, and severe water restrictions were imposed on all water users throughout South Florida. This ranged from substantial cutbacks on agricultural users to restrictions on use of home sprinklers and car washing. The managed recession accounted for $30 \mathrm{~cm}$ of lost water on the lake (with $>150 \mathrm{~cm}$ subsequently lost to evapotranspiration and water deliveries), so it is likely that these restrictions would have taken place regardless of whether or not the recession had been approved. However, it is unknown how the managed recession may have affected the initiation date or duration of these restrictions. Given the overlapping timing of the managed recession and the drought, it was difficult, if not impossible, to distinguish between the two in the public's mind.

Although normal to above-normal precipitation returned to South Florida in the fall of 2001 (Fig. 5), thereby abating the water shortage crisis, the restrictions during 2000-2001 resulted in public acrimony and economic hardships throughout the region. Not only were there water use restrictions in the South Florida region, but also economic impacts were felt by citrus, rice, and other agricultural industries, bait shop owners, hotel operators, fishing guides, trailer parks, and other segments of the economy integrally linked to public use of the lake resource. During the drought, Governor Jeb Bush of Florida declared a state of emergency, allowing smallbusiness owners to apply for low-interest loans. The main users of these loans were the commercial seinefishing operators, who were not able to do any fishing when lake stage levels were low (John Morgan, SFWMD, personal communication).

Fig. 7. Presence-absence of SAV (submerged aquatic vegetation) in Lake Okeechobee, October 2000.

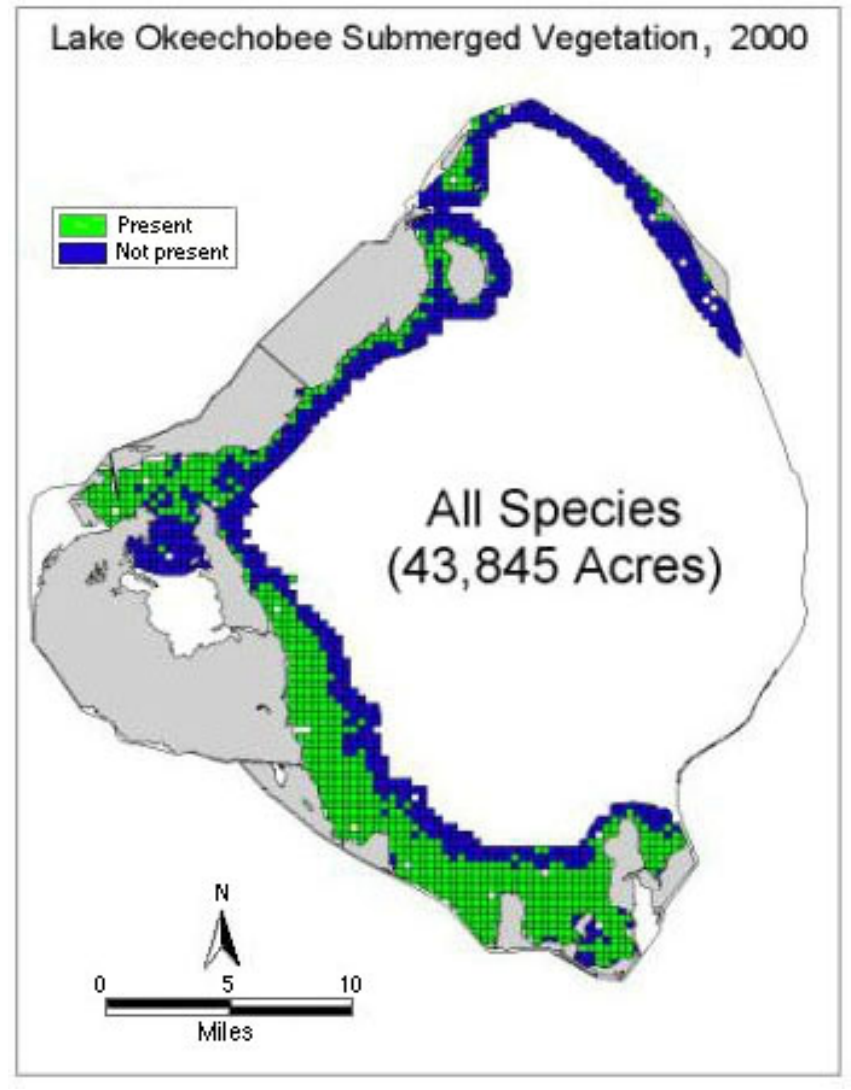

Other Implications. Immediately after the Governing Board of the SFWMD approved the Shared Adversity Plan to lower the level of Lake Okeechobee, Lee County, Florida filed a temporary injunction to halt the managed recession. The Lee County Circuit Court, following a one-day hearing, denied the injunction based on the finding that the releases would not constitute irreparable harm and that the emergency action was executive in nature. This decision was upheld in October 2000, when the District Court of Appeal of Florida concluded that the Governing Board of the SFWMD was within its discretion and the law in approving the managed recession. The District Court also noted in its ruling that it was possible that the SFWMD might have acted sooner on behalf of lake health and used a longer, more deliberative process. Court hearings were awkward for estuarine 
scientists at the SFWMD who were called to testify in support of the agency's Shared Adversity Plan. These scientists had developed personal and professional relationships with stakeholders in the estuaries. However, it was necessary for them to defend the SFWMD's overall position on the managed recession, even though short-term, negative impacts were anticipated in the estuaries.

\section{CONCLUSIONS}

Lake Okeechobee, Florida, USA has experienced serious environmental problems for the past 30 years (Aumen 1995, Havens et al. 1996, Steinman et al. 1999). Various programs have been initiated to restore the lake, but its condition continues to deteriorate. A comprehensive restoration program for the lake is now in place, supported by Florida legislation, but it will take a considerable long-term commitment of money and cooperation among a diverse stakeholder community to succeed.

The managed recession that was implemented to lower water levels was successful in terms of restoring submerged aquatic vegetation (SAV) to the lake, but it was not considered a success by some stakeholder groups, whose values of the lake placed greater weight on water supply. This managed recession helps to identify new issues and reinforces previously identified ones regarding ecosystem restoration:

1) Management actions must be based on sound and rigorous science (but see below).

2) The science must be communicated in such a manner so that lay persons can understand the basic issues without getting overwhelmed in detail (Aumen and Havens 1997, Schiller et al. 2001).

3) Involving stakeholders from the outset is essential, but does not guarantee that they will work together or come to agreement on a course of action.

4) A successful restoration effort is in the eye of the beholder. Success should be defined before the process begins to ensure that all stakeholders are working with the same definition.

5) Pragmatism is required; no matter how sound the science, operational decisions are made within a political framework.

Numerous actions are ongoing or planned for the restoration of both Lake Okeechobee and South Florida as a whole. At the regional scale, the South Florida ecosystem currently is slated for a restoration effort of unprecedented cost and magnitude (Harwell 1998). An overarching, multi-decadal restoration program for the entire Kissimmee-OkeechobeeEverglades ecosystem, referred to as the Comprehensive Everglades Restoration Plan (CERP), consisting of more than 60 major elements at an estimated cost of $\$ 7.8$ billion, is currently being implemented. However, competing societal pressures for water supply, flood control, and environmental resources, coupled with climatic conditions that have pushed the existing infrastructure to its environmental and engineering limitations, have resulted in some situations in which more immediate, short-term restoration activities are required (Redfield 2000), such as the situation described herein for Lake Okeechobee. The implementation and assessment of the Shared Action Plan has triggered a broad array of near-, mid-, and long-term actions that are geared to address the problems and constraints that existed prior to the problem. Significant public input will be utilized in the planning, design, and construction of each of these actions.

\section{Near-term actions}

1) A new regulation schedule for Lake Okeechobee was implemented in July 2000 upon approval of the USACE. This schedule will reduce the frequency of prolonged periods of high water in the lake's marsh zone, and modeling results have shown that there will be a reduction in the need for large, potentially damaging discharges to the estuaries.

2) The new regulation schedule also provides more operational flexibility, allowing the SFWMD and USACE to carry out pro-active, low-volume discharges during periods when high rainfall is expected. This will reduce the risk of high-volume, damaging discharges to downstream ecosystems when the lake rises to a higher stage. There also is the opportunity for water deliveries to the estuaries and Everglades Water Conservation Areas, as required, to alleviate stress in these downstream ecosystems caused by high salinity and low water levels, respectively.

3) The SFWMD's water contingency plan was updated to ensure that the agency is prepared for drought management. 
4) A torpedograss management plan was developed that includes a schedule for treating all or most of this invasive plant during the next decade.

\section{Mid-term actions}

1) A series of operational changes to the plumbing infrastructure in South Florida will allow water to be stored in other areas besides Lake Okeechobee. These include a series of stormwater treatment areas, providing a minimum of 250,000 acre-feet (about $308,372 \mathrm{~km}^{2}$ ) per year of additional storage.

2) Additional water storage of between 20,000 and 60,000 acres $\left(80,937-242,812 \mathrm{~km}^{2}\right)$ may be provided in the Everglades Agricultural Area, immediately south of Lake Okeechobee, by 2009.

3) Additional water storage of approximately 400,000 acre-feet $\left(493,395 \mathrm{~km}^{2}\right)$ in aboveground reservoirs near Lake Okeechobee by 2007 is called for in CERP.

\section{Long-term actions}

1) CERP calls for additional water storage and treatment facilities in the Lake Okeechobee watershed, which may include components such as reservoirs, stormwater treatment areas, wetland restoration, and sediment removal. CERP also includes many aquifer storage and recovery (ASR) wells around the lake. The goal of the projects is to capture peak runoff from the watershed to reduce the frequency and duration of high water levels that damage the littoral zone and result in damaging releases to the estuaries. Planning for these projects has begun, but final completion will not occur until 2015.

2) CERP also includes the construction of aboveground reservoirs (160,000 acre-feet; 197,358 $\mathrm{km}^{2}$ ) and ASR wells with capacity of 220 million gallons $\left(83,279 \mathrm{~m}^{3}\right.$ per day in the Caloosahatchee basin, to handle runoff from Lake Okeechobee before it reaches the estuary. Implementation is scheduled for 2012.

3) The decision to lower the water level in Lake Okeechobee was driven by a combination of political and environmental factors. Science provided the justification for the Governing Board of the SFWMD to make a difficult decision. In this case, the science behind the decision was relatively transparent, as much of it was aired publicly and presented in a format that was meant to be understood by a nonscientific audience. The pressure for use of our aquatic resources continues to grow, both globally and especially in South Florida, as a function of population growth. Scientific input will be essential if humans are to successfully balance the competing demands on aquatic ecosystems, allowing these systems to provide societal services and still function in a natural manner. Hopefully, the lessons learned from both the successes and failures associated with this event will be adopted in future resource management decisions.

Responses to this article can be read online at: http://www.consecol.org/vol6/iss2/art17/responses/index.html

\section{Acknowledgments:}

The authors are grateful to Jayantha Obeysakara, Dean Powell, Luis Cadavid, Peter Doering, Fred Sklar, Carl Fitz, Mark Brady, Chuck Hanlon, Tommy Swift, Ken Ammon, and Patricia Strayer for their various roles in data collection, data analysis, or support during this project. Comments from Susan Gray, Peter Doering, and two anonymous reviewers are appreciated.

\section{LITERATURE CITED}

Aumen, N. G. 1995. The history of human impacts, lake management, and limnological research on Lake Okeechobee, Florida (USA). Archiv für Hydrobiologie Beiheft Ergebnisse der Limnologie 45:1-16.

Aumen, N. G., and R. G. Wetzel. 1995. Ecological studies on the littoral and pelagic systems of Lake Okeechobee, Florida (USA). Archiv für Hydrobiologie Beiheft Ergebnisse der Limnologie 45:1-356.

Aumen, N. G., and K. E. Havens. 1997. Needed: a new cadre of applied scientists skilled in basic science, communication, and aquatic resource management. Journal of the North American Benthological Society 16:710-716.

Cadavid, L. G., R. VanZee, C. White, P. Trimble, and J. T. B. Obeysekera. 1999. Operational hydrology in south Florida using climate forecast. Pages 51-66 in Proceedings of the Annual Conference of the American Geophysical Union.

Carpenter, S. R., N. F. Caraco, D. L. Correll, R. W. Howarth, A. N. Sharpley, and V. H. Smith. 1998. Nonpoint pollution of surface waters with phosphorus and nitrogen. Ecological Applications 8:559-568. 
Dahm, C. N., K. W. Cummins, H. M. Valett, and R. L. Coleman. 1995. An ecosystem view of the restoration of the Kissimmee River. Restoration Ecology 3:225-238.

David, P. G. 1999. Response of exotics to restored hydroperiod at Dupuis Reserve, Florida. Restoration Ecology 7:407-410.

Doering, P. H., R. H. Chamberlain, K. M. Donohue, and A. D. Steinman. 1999. Effect of salinity on the growth of Vallisneria americana Michx. from the Caloosahatchee Estuary, Florida. Florida Scientist 62:89-105.

Furse, J. B., and D. D. Fox. 1994. Economic fishery valuation of five vegetation communities in Lake Okeechobee, Florida. Proceedings of the Annual Conference of Southeastern Association of Fish and Wildlife Agencies 48:575-591.

Hall, A. 1992. Guide for the management of high stages of Lake Okeechobee. Report, South Florida Water Management District, West Palm Beach, Florida, USA.

Hanlon, C. G., and K. Langeland. 2000. Comparison of experimental strategies to control torpedograss. Journal of Aquatic Plant Management 38:40-47.

Harwell, M. A. 1998. Science and environmental decision making in south Florida. Ecological Applications 8:580590.

Havens, K. E., N. G. Aumen, R. T. James, and V. H. Smith. 1996. Rapid ecological changes in a large subtropical lake undergoing cultural eutrophication. Ambio 25:150-155.

Havens, K. E., M. C. Harwell, M. A. Brady, B. Sharfstein, T. L. East, A. J. Rodusky, D. Anson, and R. P. Maki. 2002. Large-scale mapping and predictive modeling of submerged aquatic vegetation in a shallow eutrophic lake. TheScientificWorld 2:949-965.

Havens, K. E., and R. T. James. 1999. Localized changes in transparency linked to mud sediment expansion in Lake Okeechobee, Florida: ecological and management implications. Lake and Reservoir Management 15:54-69.

Havens, K. E., K.-R. Jin, A. J. Rodusky, B. Sharfstein, M. A. Brady, T. L. East, N. Iricanin, R. T. James, M. C. Harwell, and A. D. Steinman. 2001. Hurricane effects on a shallow lake ecosystem and its controlled manipulation of water level. TheScientificWorld 1:44-70.

Havens, K. E., and C. L. Schelske. 2001. The importance of considering biological processes when setting total maximum daily loads (TMDL) for phosphorus in shallow lakes and reservoirs. Environmental Pollution 113:1-9.

Hirsch, R. M. 1978. Risk analysis for a water supply system: Occoquan Reservoir, Fairfax and Prince William Counties, Virginia. Hydrologic Science Bulletin 23:476505.
Kraemer, G. P., R. H. Chamberlain, P. H. Doering, A. D. Steinman, and M. D. Hanisak. 1999. Physiological responses of Vallisneria americana transplants along a salinity gradient in the Caloosahatchee Estuary (SW Florida). Estuaries 22:138-148.

Matson, P. A., W. J. Parton, A. G. Power, and M. J. Swift. 1997. Agricultural intensification and ecosystem properties. Science 277:504-509.

NRC (National Research Council). 1992. Restoration of aquatic ecosystems: science, technology, and public policy. National Academy Press, Washington, D.C., USA

Postel, S., and S. R. Carpenter. 1997. Freshwater ecosystem services. Pages 195-214 in G. Daily, editor. Nature's services. Island Press, Washington, D.C., USA.

Redfield, G. W. 2000. Ecological research for aquatic science and environmental restoration in south Florida. Ecological Applications 10:990-1005.

Schiller, A., C. T. Hunsaker, M. A. Kane, A. K. Wolfe, V. H. Dale, G. W. Suter, C. S. Russell, G. Pion, M. H. Jensen, and V. C. Konar. 2001. Communicating ecological indicators to decision makers and the public. Conservation Ecology 5:19.

SFWMD (South Florida Water Management District). 1997. South Florida Water Management Model, Version XX, Documentation. Hydrologic Systems Modeling Division, South Florida Water Management District, West Palm Beach, Florida, USA.

SFWMD (South Florida Water Management District). 1999. Focus on the St. Lucie River. [Available online: http://www.sfwmd.gov/org/wrp/wrp_ce/2_wrp_ce_info/stlu cie.pdf.

SFWMD (South Florida Water Management District). 2000. Resolution concerning immediate, short-term actions to lower Lake Okeechobee water levels. Resolution Number 00-31A, South Florida Water Management District, West Palm Beach, Florida, USA.

SFWMD (South Florida Water Management District). 2001. Everglades consolidated report. South Florida Water Management District, West Palm Beach, Florida, USA.

Steinman, A. D., K. E. Havens, N. G. Aumen, R. T. James, K.-R. Jin, J. Zhang, and B. H. Rosen. 1999. Phosphorus in Lake Okeechobee: sources, sinks, and strategies. Pages 527-544 in K. R. Reddy, G. A. O'Connor, and C. L. Schelske, editors. Phosphorus biogeochemistry of subtropical ecosystems: Florida as a case example. CRC Press, Boca Raton, Florida, USA.

Steinman, A. D., K. E. Havens, H. J. Carrick, and R. VanZee. 2001. The past, present, and future hydrology and ecology of Lake Okeechobee and its watersheds. Pages 1937 in J. W. Porter and K. G. Porter, editors. The Everglades, 
Florida Bay, and Coral Reefs of the Florida Keys. CRC Press, Boca Raton, Florida, USA.

Steinman, A. D., K. E. Havens, A.J. Rodusky, B. Sharfstein, R.T. James, and M. C. Harwell. 2002. The influence of environmental variables and a managed water recession on the growth of charophytes in a large, subtropical lake. Aquatic Botany 72:297-313.

Steinman, A. D., R. H. Meeker, A. J. Rodusky, W. P. Davis, and S.-J. Hwang. 1997. Ecological properties of charophytes in a large, subtropical lake. Journal of the North American Benthological Society 16:781-793.

Tasker, G. D., and P. Dunne. 1997. Bootstrap position analysis for forecasting low flow frequency. Journal of Water Resources Planning and Management, ASCE 123:359-367.

USACE (United States Army Corps of Engineers). 1999. Central and Southern Florida Project comprehensive review study, final integrated feasibility report and programmatic environment impact statement. U.S. Army Corps of Engineers, Jacksonville, Florida, USA.

Vitousek, P. M., H. A. Mooney, J. Lubchenco, and J. M. Melillo. 1997. Human domination of earth's ecosystems. Science 277:494-499.

Wackernagel, M., N. B. Schulz, D. Deumoing, A. Callejas Linares, M. Jenkins, V. Kapos, C. Monfreda, J. Loh, N. Myers, R. Norgaard, and J. Randers. 2002. Tracking the ecological overshoot of the human economy. Proceedings of the National Academy of Sciences (USA) 99:9266-9271.

Zimba, P. V., M. S. Hopson, J. P. Smith, D. E. Colle, and J. V. Shireman. 1995. Chemical composition and distribution of submersed aquatic vegetation in Lake Okeechobee, Florida (1989-1991). Archiv für Hydrobiologie. Advances in Limnology 45:241-246. 